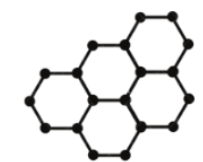

ICONSMAT

Institute of
Construction Materiers
Content list available at ICONSMAT

Journal of Construction Materials

Journal homepage: www.iconsmat.com.au/publication
Article history:

Received 5 May 2021

Received in revised form

15 June 2021

Accepted 3 May 2021

Available online 4 July 2021

\title{
Negative interest rate: Way to tackle inflationary housing prices
}

\author{
Farid Sartipi ${ }^{1 *}$ \\ 1* Corresponding author: E: farid.sartipi@iconsmat.com.au; Institute of Construction Materials
}

\begin{abstract}
While housing affordability is on drop by the rising prices, specially in large cities, the young generation suffers from the pending independence as a result. Despite the significantly good industrial performance in the construction sector in Australia, reduced housing prices is still under burden by the middle mans and real estate brokers. Several socio-economic factors are indeed involved in the rising prices such as unequal wealth distribution, banking strategies, wages growth rate, mortgage interest rate, population growth, etc. which are being discussed in this article. Data had been collected from the Australian Bureau of Statistics in order to compare and analyze the effectiveness of negative interest rates on housing affordability. New financial asset classes such as cryptocurrencies had also been introduced in order to propose alternatives to the traditional investment banking which also ensures profit earning for bankers.
\end{abstract}

DOI: 10.36756/JCM.v2.4.1 C2021 Institute of Construction Materials

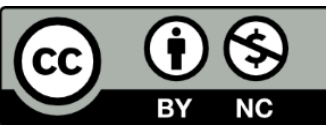

\section{Keywords}

Negative interest rate; Housing affordability; Banking; Cryptocurrency 


\section{Introduction}

In a period of rising social inequalities in the advanced economies, lower and middle-class households see evaporating opportunities as the concentrated wealth in these economies had started to become a challenge for several decades [1]. Throughout the history, governments proposed economic stimulus and recovery packages at the times of crisis and, conversely, much of the so-called recovery wealth by about $95 \%$ is regained by the top one percent of the society [2]. Indeed, there are many dimensions to what defines the general term for wealth; housing being one of them. Individuals economic security is being underlined by home ownership in a variety of contexts [3]. While many younger, lower income and more precarious households experience the diminishing housing wealth attainment, housing price gains leads to additional wealth accumulation among the top classes of the society [4].

Housing is commonly known as the most valuable financial asset held by the households [5]. Because of that, housing prospects are accordingly being considered as the root to the economic inequality. From the same point of view, housing is characterized as a form of financial asset which is more difficult to quickly or fully capitalize and therefore financial institutions such as banks are being more cautious about the equity value on paper as it may not precisely reflect the real value accessible value of the asset [6]. The idea of "asset-based welfare" in many advanced economies which had started to gain popularity from decades ago, scales the need for homeownership as families with an statues of an owner in such societies are believed to have a more secured financial position [3, 7, 8]. Governments, indeed, support this idea as the welfare support in this scheme shifts toward the individual households rather than public support.

As homeownership in todays advanced societies becomes increasingly important to individual's financial security, it is crucial to identify the drivers of inequality. Indeed, homeownership required some economic capacities such as reliable labour market that can support the pay offs. However, the transformation of the labour market over the recent decades have resulted in both growing polarization and rising employment insecurity. Another driver of inequality today is the ineffective mortgage system which exacerbates the status of concentrated wealth. In such system, the wealthy becomes wealthier, and the poor becomes poorer. Altogether (figure 1), the consequent rising house prices and inequality had made the homeownership difficult especially for the young first-time-buyers [9].

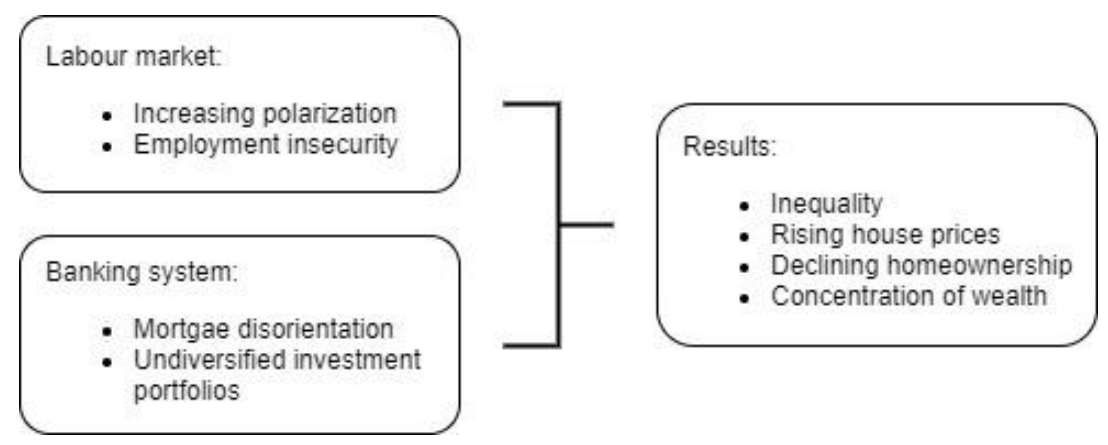

Figure 1- Key drivers of housing wealth polarization

\section{Wage's growth rate}

Throughout the past decades, job market has seen progressive shifts towards polarization and employment insecurity such as youth unemployment, underemployment, and income disparity [1013]. As unemployment level follows cyclic up and down turns, in stable conditions, the returned jobs are less likely to be full-time. Rather, part-time and casual contracts replace the previous full-time 
positions with less security. Even with a sufficient income level, the precarious employment often deny access to mortgage credits as well as impacting the decision to buy a house. These reduced economic capacities exhibit a significant intergenerational polarity between the wealthy and the poor.

Individuals to be able to afford homeownership are meant to be capable of paying back the mortgage terms. The Australian Bureau of Statistics reports a 1.8\% wages growth rate in June quarter 2020 on a declining slope. This means that in a perfect world, an individual with a secured full-time contract can expect $1.8 \%$ increase in his/her salary as the years pass on. The same person in 2006 could expect $4 \%$ increase in his/her salary.

Annual WPI growth - 1997 to 2020

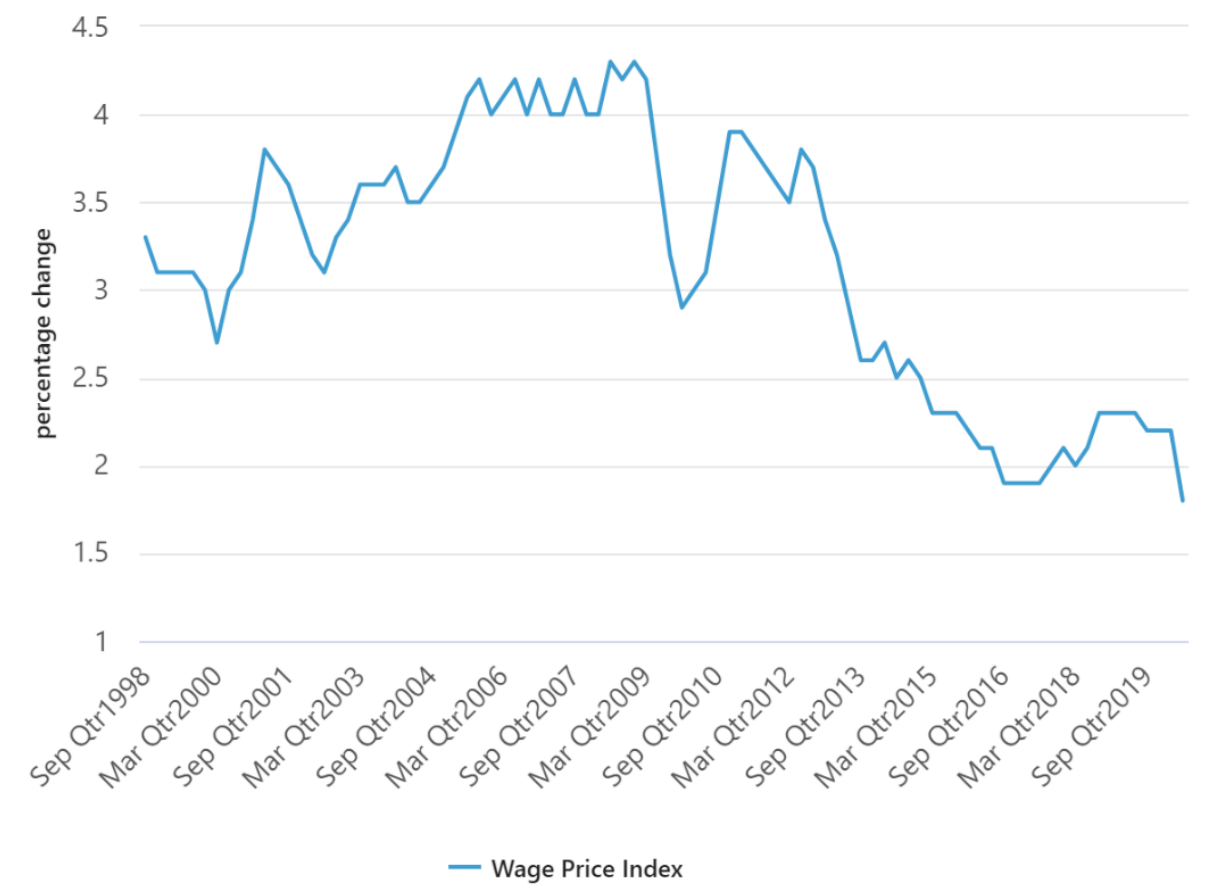

Source: Australian Bureau of Statistics, Annual wage growth 1.8\% in June quarter 2020

Figure 2 - Australian historic wage's growth rate

There are several implications as to why the wage's growth rate follows a declining slope. Purchasing power and controlling the national inflation rate can be one of them. Indeed, higher salaries empowers individuals to buy more and that itself causes the sellers to ask for more i.e. rise in inflation and currency devaluation. So, governments in order to control the inflation rate, tend to create a sense of scarcity as it causes the value of something, in this case currency, to grow. Although it may also cause hardship and eventually opposing movements if continues without a comprehensive plan. Another reason for the declining wage's growth rate can be due to the rising globalization. Outsourcing jobs to overseas especially in the internet environment are often the first choice of business owners if the price of service or a product in the international markets are lower. In such cases, businesses tend to pay international suppliers as their prices are low. It is particularly applicable to the Australian condition as the Australian dollar has a massive purchasing power all over the world. A possible way to tackle the outsourcing of jobs is by empowering domestic manufacturing. Goods and services made and sold inside the country secure the jobs and better wages arrangement. 


\section{Mortgage interest rate}

On top of any other factors affecting the housing prices, mortgage interest rate is seemed to be the most effective one. Depending on the installments and the terms of the mortgage the borrower after settling all the amount owed to the bank may decide to sell his/her dwelling with a profit margin. This typical purchase behaviour is the very basic reason for the inflationary housing prices as rational individuals like to become richer. The Reserve Bank of Australia outlines the lenders' interest rate for both housing and business sectors. The historic graphs published by this entity shows a downward trend in the past years which itself is a good indication for a better housing affordability (figure 3) currently at slightly above $2.75 \%$. However, when it is compared with the wages growth rate (figure 2 ) that is currently at $1.8 \%$, individual buyers have no choice other than failing to pay off the total mortgage amount. It is true based on the assumption that individuals are full time workers without any other source of income.

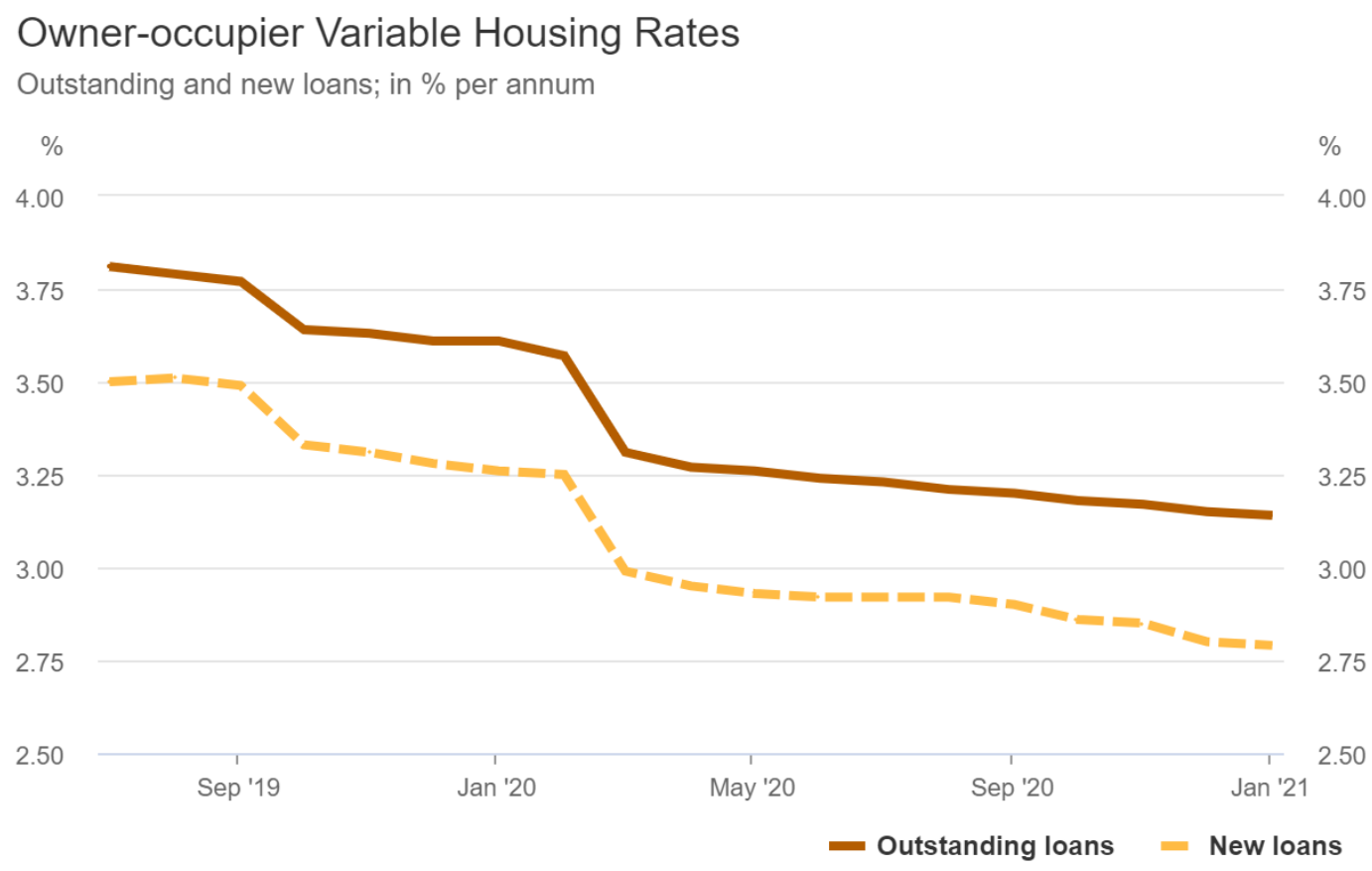

Sources: APRA; RBA

Figure 3 - Lenders' interest rate outlined by the Reserve Bank of Australia.

According to the reports released by Domain Real Estate, one of the largest agents in Australia, an average house in Sydney costs roughly about $\$ 1.2 \mathrm{M}$ with a growth rate of $6.7 \%$ per annum which ranks Sydney as the most expensive city in Australia in terms of housing prices. Given this information, the individual full-time workers who fall behind the mortgage payments by $0.95 \%$ (the difference between wages growth rate and lenders' interest rate) must earn $\$ 11,509$ each year from other sources of income. Table 1 shows the breakdown of mortgage short falls for other capital cities in Australia. 
Table 1 - Australia's average housing prices reported by Domain Real Estate [14]

\begin{tabular}{cccc}
\hline \hline City & Average house price & Growth rate & Annual mortgage shortfall \\
\hline Sydney & $\$ 1,211,488$ & $+6.7 \%$ & $\$ 11,509.14$ \\
Melbourne & $\$ 936,073$ & $+3.9 \%$ & $\$ 8,892.69$ \\
Brisbane & $\$ 616,387$ & $+5.6 \%$ & $\$ 5,855.68$ \\
Adelaide & $\$ 574,264$ & $+6.1 \%$ & $\$ 5,455.51$ \\
Canberra & $\$ 855,530$ & $+9.1 \%$ & $\$ 8,127.54$ \\
Perth & $\$ 563,214$ & $+6.3 \%$ & $\$ 5,350.53$ \\
Hobart & $\$ 564,091$ & $+12.4 \%$ & $\$ 5,358.86$ \\
Darwin & $\$ 533,845$ & $+3.6 \%$ & $\$ 5,071.53$ \\
\hline National & $\$ 852,940$ & $+5.8 \%$ & $\$ 8,102.93$ \\
\hline \hline
\end{tabular}

\section{Negative interest rate}

Implementing negative interest rate policies (NIRP) historically occurred once governments decide to devalue a particular asset. Swiss National Bank, for example, in 1970 introduced negative interest rate on foreign deposits to prevent capita inflows and excessive appreciation of the Swiss franc [15]. NIRP had been often put into effect by the federal/national banks. In such situations, excessive care must be taken as long-term implementation of NIRP can have a diverse effect on emerging markets and developing economies [16]. Nevertheless due to the positive outcomes of implementing this policy, many countries had now embraced NIRP such as Denmark National Bank (DNB), the European Central Bank (ECB), the Swiss National Bank (SNB), Swedish Riksbank, Bank of Japan (BoJ), and the Central Bank of Hungary [16]. The complementary policies announced following the NIRP by the European Central Bank were due to the reasons below:

- Targeted refinancing operations program with 2-year maturity. Initiated to facilitate asset backed securities purchase program (rates from $-0.10 \%$ to $-0.3 \%$ ).

- Expanded size of quantitative easing program from €60 billion to €80 billion per month (at $0.4 \%)$.

The lowest negative interest rate ever recorded according to the reports by the so-called central banks was $-0.75 \%$ in February 2015 initiated by Denmark National Bank and Swiss National Bank at the same time.

Monetary policies in advanced economies occasionally have to account for weak demand for money depending on the economic cycle. In such circumstances, consumers often have excessive amount of savings and are able to pay for goods and services on much higher prices. In a situation like so, central banks decide to impose charge fees on holding money for account holders in order to encourage more purchase [17].

In the context of housing market, investment bankers currently charge positive mortgage interest rates which had been studied to be the main reason behind the inflationary housing prices. It might not seem viable for bankers to go negative in the first place as it causes loss. However, based on the most basic principle of investment, being diversification $[18,19]$, a healthy investment portfolio consists of various types of assets with different liquidity ratios. It is in fact the same principle (diversification) which allows to lower the risk of loss. Thus, if banks decide to impose negative mortgage interest rates in order to close the inequality gap and a better social practice, another asset type must be structured well enough to ensures profitability of the whole portfolio; Given that bankers only care about profit. This is indeed 
applicable if the law is enforced which can be different to the natural flow of supply and demand in the housing market.

From the perspective of supply and demand, also, the economy must lean towards more supply of new houses for the purpose of observing the decline in house prices. Demand, in this context, is derived by the population growth. Table 2 shows the relevant statistics to population growth across Australia. In terms of supply however, NSW Department of Planning, Industry, and Environment forecasts 132,000 to 171,200 new homes will be built in the 5-year period of 2020-2025 [20]. A simple comparison between the population growth of 50,600 (demand based on the assumption that each person seeks homeownership) and the minimum supply of 132,000 new homes indicates the surplus of housing which leads to a lower housing prices.

Table 2 - Australian population growth by state (Source: Australian Bureau of Statistics)

\begin{tabular}{cccc}
\hline \hline & $\begin{array}{c}\text { Population at 30 Sep 2020 } \\
\text { ('000) }\end{array}$ & $\begin{array}{c}\text { Change over previous year } \\
\text { ('000) }\end{array}$ & $\begin{array}{c}\text { Change over previous year } \\
\text { (\%) }\end{array}$ \\
\hline New South Wales & $8,166.40$ & 50.6 & 0.6 \\
Victoria & $6,680.60$ & 47.2 & 0.7 \\
Queensland & $5,184.80$ & 68.2 & 1.3 \\
South Australia & $1,770.60$ & 12.7 & 0.7 \\
Western Australia & $2,667.10$ & 32.6 & 1.2 \\
Tasmania & 541.1 & 5.3 & 1 \\
Northern Territory & 246.5 & 0.4 & 0.2 \\
Australian Capital Territory & 431.2 & 3.4 & 0.8 \\
\hline Australia & $25,693.10$ & 220.5 & 0.9 \\
\hline \hline
\end{tabular}

To diversify the investment banking portfolios, cryptocurrencies had shown a reliable and profitable growth rate that can be seen as a mitigation to negative mortgage interest rates. Specially the Ethereum blockchain had introduced promising protocol for businesses who are seeking to go public via the means of ERC20 protocol [21].

The phenomenon that threatens the adoption of negative interest rate on mortgage rates is foreign investment in the Australian property market which, if not controlled, can put wellbeing of Australians under ambiguity. Thus, the regulatory bodies such as land registries must ensure appropriate measures for ownership entitlements. Yet another set of factors that can also possibly act in contrary to the principles of negative mortgage rates are those related to climate change actions and reducing the energy consumption of residential/commercial properties. In a study done by D. Hagare et al. [22] it has been predicted that in a 5 year perspective until 2025-26 the housing prices can move even higher by an average amount of around $\$ 78,000$ due to the implementation of environmental building designs. Such technologies [23-26] are still not available in mass which can be seen as a shortage in supply meanwhile the demand is surging. 


\section{Conclusion}

In the light of diminishing social inequality and youth independence, negative mortgage interest rates had been studied to be effective. Examples from European central banks and the natural law of supply and demand, in a quantitative approach, shows the declining housing prices in Australia. In that respect, population growth and governmental forecast on the supply of new housings had been considered in this study. However, profit-driven bankers may find it not viable to implement negative interest rates at the first sight. In order to satisfy the profitability of investment banking, cryptocurrencies had been proposed to be added in the relevant portfolios which helps in mitigation of the negative interest rates.

\section{References}

[1] R. Arundel, "Equity inequity: Housing wealth inequality, inter and intra-generational divergences, and the rise of private landlordism," Housing, Theory and Society, vol. 34, no. 2, pp. 176200, 2017.

[2] J. E. Stiglitz, The price of inequality: How today's divided society endangers our future. WW Norton \& Company, 2012.

[3] J. Doling and R. Ronald, "Home ownership and asset-based welfare," Journal of housing and the built environment, vol. 25, no. 2, pp. 165-173, 2010.

[4] P. A. Kemp, "Private renting after the global financial crisis," Housing Studies, vol. 30, no. 4, pp. 601-620, 2015.

[5] K. Rowlingson and S. D. McKay, Wealth and the Wealthy: Exploring and tackling inequalities between rich and poor. Policy Press, 2011.

[6] O. Bonnet, P.-H. Bono, G. Chapelle, and E. Wasmer, "Does housing capital contribute to inequality? A comment on Thomas Piketty's Capital in the 21st Century," Sciences Po Economics Discussion Papers, vol. 7, p. 12, 2014.

[7] D. Conley and B. Gifford, "Home ownership, social insurance, and the welfare state," in Sociological forum, 2006, vol. 21, no. 1: Springer, p. 55.

[8] P. Saunders, A nation of home owners. Routledge, 2021.

[9] C. Hay, "Common trajectories, variable paces, divergent outcomes? Models of European capitalism under conditions of complex economic interdependence," Review of international political economy, vol. 11, no. 2, pp. 231-262, 2004.

[10] B. Nolan et al., Changing inequalities and societal impacts in rich countries: thirty countries' experiences. OUP Oxford, 2014.

[11] K. McKee, "Young people, homeownership and future welfare," Housing Studies, vol. 27, no. 6, pp. 853-862, 2012.

[12] M. C. Buchmann and I. Kriesi, "Transition to adulthood in Europe," Annual review of sociology, vol. 37, pp. 481-503, 2011.

[13] R. Arundel and J. Doling, "The end of mass homeownership? Changes in labour markets and housing tenure opportunities across Europe," Journal of Housing and the Built Environment, vol. 32, no. 4, pp. 649-672, 2017.

[14] S. Marsh, "Australia's average house price hits record high as buyers flood market post-COVID," in 9NEWS, ed: 9NEWS, 2021. 
[15] P. Meggyesi, "Reflections on negative interest rates in Switzerland," JP Morgan, May, vol. 14, p. 2010, 2010.

[16] C. Arteta, M. A. Kose, M. Stocker, and T. Taskin, "Implications of negative interest rate policies: An early assessment," Pacific Economic Review, vol. 23, no. 1, pp. 8-26, 2018.

[17] L. H. Summers, "US economic prospects: Secular stagnation, hysteresis, and the zero lower bound," Business economics, vol. 49, no. 2, pp. 65-73, 2014.

[18] K. Śmietana, "Diversification principles of real estate portfolios," Real Estate Management and Valuation, vol. 22, no. 1, pp. 51-57, 2014.

[19] V. Avadhani, Investment management. Himalaya Publishing House, 2010.

[20] (2021). Sydney Hosing Supply Forecast. [Online] Available: https://www.planning.nsw.gov.au/Research-and-Demography/Sydney-Housing-Supply-Forecast

[21] F. Sartipi, "Publicizing construction firms by cryptocurrency," Journal of Construction Materials, vol. 2, pp. 3-1, 2021, doi: https://doi.org/10.36756/JCM.v2.3.1.

[22] H. Albayyaa, D. Hagare, and S. Saha, "Energy conservation assessment of traditional and modern houses in Sydney," Building Research \& Information, pp. 1-11, 2021.

[23] F. Sartipi, "Dynamic data processing for building energy consumption," Journal of Construction Materials, vol. 2, no. 2021, pp. 2-4, 2020, doi: https://doi.org/10.36756/JCM.v2.2.4.

[24] F. Sartipi, "Automatic sorting of recycled aggregate using image processing and object detection," Journal of Construction Materials, vol. 1, pp. 3-3, 2020, doi: https://doi.org/10.36756/JCM.v1.2.1.

[25] F. Sartipi, "Diffusion of Innovation Theory in the Realm of Environmental Construction," Journal of Construction Materials, vol. 1, pp. 4-2, 2020, doi: https://doi.org/10.36756/JCM.v1.3.2.

[26] F. Sartipi, A. Ghari Zadeh, and M. Gamil, "Electrical resistance of graphene reinforced cement paste," Journal of Construction Materials, 2019. 